\title{
Acetylene-Substituted Phosphane Oxides: Building Blocks for Macrocycles
}

\author{
Sander G. A. van Assema, ${ }^{\text {[a] }}$ G. Bas de Jong, ${ }^{\text {[a] }}$ Andreas W. Ehlers, ${ }^{\text {[a] }}$ Frans J. J. de Kanter, ${ }^{\text {[a] }}$ \\ Marius Schakel, ${ }^{[a]}$ Anthony L. Spek, ${ }^{[b]}$ Martin Lutz, ${ }^{[b]}$ and Koop Lammertsma* ${ }^{*[a]}$
}

Keywords: Phosphorus heterocycles / Alkynes / Macrocycles / Cross-coupling / Phosphanes

Phosphorus-based macrocycles with acetylenic scaffolds have been built from acetylene-substituted phosphane oxides that were formed from diisopropylphosphoramidic dibromide (3) and an acetylenic Grignard reagent. The fourand six-edged macrocycles 15 and 16, in which the $i \operatorname{Pr}_{2} \mathrm{NP}(\mathrm{O})$ units are connected through 1,3-butadiyne rods, were obtained from the monosilylated derivative of $i \operatorname{Pr}_{2} \mathrm{NP}(\mathrm{O})\left(\mathrm{C}_{2} \mathrm{H}\right)_{2}$ (7) by multiple acetylene coupling reactions under oxidative
Hay conditions. Reaction of $i \operatorname{Pr}_{2} \mathrm{NP}(\mathrm{O})(\mathrm{Br})_{2}(3)$ with lithiated 1,2-diethynylbenzene gave a mixture of cis and trans monocyclic bis(phosphane oxide) 18. An X-ray crystal structure determination of the trans isomer shows the ring structure to adopt a puckered form.

(ㄷ Wiley-VCH Verlag GmbH \& Co. KGaA, 69451 Weinheim, Germany, 2007)

\section{Introduction}

Acetylenic scaffolds have been heavily pursued over the past decade, mainly because of their optoelectronic properties. $^{[1]}$ From the perspective of carbon networks, beautifully designed one-, two-, and three-dimensional scaffolds have been prepared. ${ }^{[2]}$ Remarkably, with the exception of sulfurbased molecules, heteroatoms have rarely been embedded in these rigid wires, rings, boxes, and cages. Especially in the context of the special $\mathrm{P} / \mathrm{C}$ relationship, ${ }^{[3]}$ it is surprising that hardly any attention has been paid to the incorporation of phosphorus atoms. Examples of their potential are the thiophene- and pyridine-conjugated phospholes that possess optical and electrochemical properties. ${ }^{[4]}$

Only a few examples are known of phosphorus-containing carbon skeletons. In 1990 Scott and co-workers ${ }^{[5]}$ reported on alkynyl-conjugated organophosphorus ring structures such as 1. Later, Märkl et al. ${ }^{[6]}$ reported on the synthesis of cyclic ethynylphosphanes like 2 .

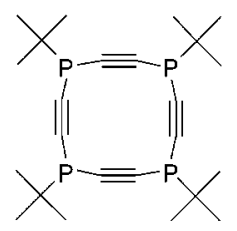

1

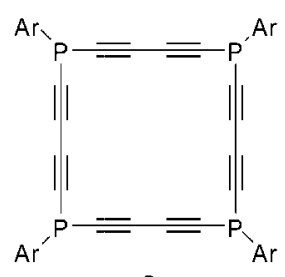

2 [a] Department of Organic and Inorganic Chemistry, Faculty of Sciences, Vrije Universiteit,

De Boelelaan 1083, 1081 HV Amsterdam, The Netherlands

[b] Bijvoet Center for Biomolecular Research, Crystal and Structural Chemistry, Utrecht University,

Padualaan 8, $3584 \mathrm{CH}$ Utrecht The Netherlands

$\square$ Supporting information for this article is available on the WWW under http://www.eurjoc.org or from the author.
In the study reported herein we used ethynylphosphane oxides as the starting point for the synthesis of cyclic $\mathrm{P} / \mathrm{C}$ frames to simplify product handling. These oxides are commonly generated from air-sensitive ethynylphosphanes by peroxide oxidation. ${ }^{[7]}$ However, we have used a diethynylphosphane oxide with an amine substituent, which has the advantage over $P$-alkyl and $P$-aryl groups in that it enables further functionalization. ${ }^{[8]}$

\section{Results and Discussion}

The synthesis and manipulation of the building blocks will be discussed first, followed by an evaluation of the Grignard and oxidative Hay coupling reactions in the construction of $\mathrm{P} / \mathrm{C}$ macrocycles. A P/C ring structure obtained from 1,2-diethynylbenzene and diisopropylphosphoramidic dibromide is described in the final section.

\section{Building Blocks}

Diisopropylphosphoramidic dibromide $\left[i \mathrm{Pr}_{2} \mathrm{NP}(\mathrm{O}) \mathrm{Br}_{2}\right]$ (3) (Scheme 1), a potential corner unit of $\mathrm{P} / \mathrm{C}$ rings, can be generated from oxygen- and moisture-sensitive $i \mathrm{Pr}_{2} \mathrm{NPBr}_{2},{ }^{[9]}$ obtained from the addition of diisopropylamine to $\mathrm{PBr}_{3}(85 \%)$, by reaction with ozone at $-78^{\circ} \mathrm{C}$ in

$$
\mathrm{PBr}_{3}+2 \mathrm{Pr}_{2} \mathrm{NH} \frac{\mathrm{Et}_{2} \mathrm{O}}{-78^{\circ} \mathrm{C}}-\mathrm{Pr}_{2} \mathrm{NPBr}_{2}+i \mathrm{Pr}_{2} \mathrm{NH} \cdot \mathrm{HBr}
$$

Scheme 1. Synthesis of $i \operatorname{Pr}_{2} \mathrm{NP}(\mathrm{O}) \mathrm{Br}_{2}$ (3). 
dichloromethane $(70 \%)$, as monitored by ${ }^{31} \mathrm{P}$ NMR spectroscopy $(+174.3 \rightarrow-34.1 \mathrm{ppm})$ for maximum conversion.

Replacing the bromines of $\mathbf{3}$ by acetylene units gives a potentially even better building block, but reaction with $\mathrm{HC} \equiv \mathrm{C}-\mathrm{MgBr}$ (2 equiv.) mainly resulted in a black unidentified (polymeric) material with only trace amounts of the dialkynylated phosphane oxide. Apparently, the Grignard reagent (or the product) is not stable under the reaction conditions. Use of the silyl-protected Grignard reagent $\mathrm{BrMgC} \equiv \mathrm{CTMS}$ (4) gave dialkynylphosphinic amide $\mathbf{6}$ $(80 \%)$ via nonisolable monoalkynylated intermediate $\mathbf{5}$ $\left[\delta\left({ }^{31} \mathrm{P}\right)=-15 \mathrm{ppm}\right]$ (Scheme 2). Purification of $\mathbf{6}$ by column chromatography with either silica gel or aluminium oxide led to partial desilylation, ${ }^{[7 \mathrm{a}]}$ whereas tetrabutylammonium fluoride (TBAF) on silica in wet THF at $-78^{\circ} \mathrm{C}$ gave full conversion into 7 (68\% isolated yield) (Scheme 2) which is a stable solid that can be kept for months when stored below $0{ }^{\circ} \mathrm{C}$. Related building blocks such as sterically protected diethynylphosphanes and butadiynylphosphanes have been reported by Yoshifuji and co-workers. ${ }^{[10]}$
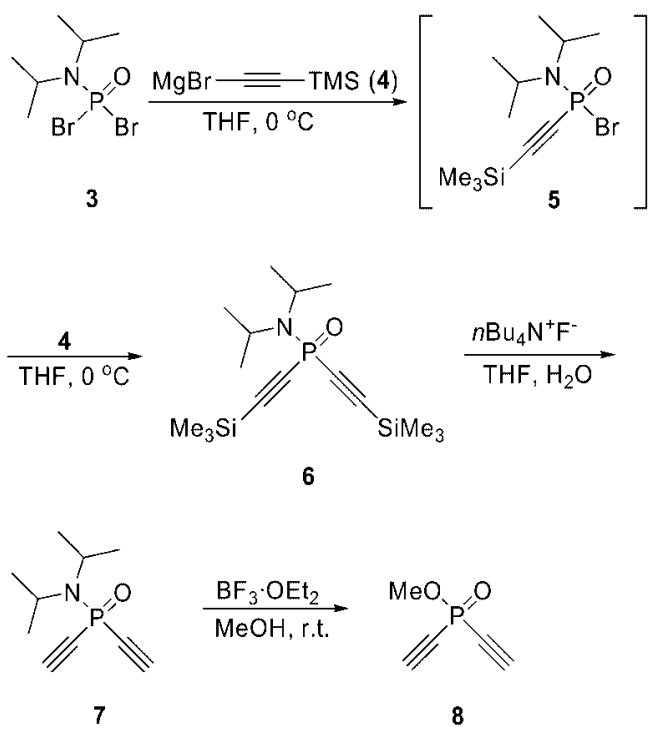

Scheme 2. Synthesis of phosphinic amide 7 and phosphinate $\mathbf{8}$.

Whereas 7 did not hydrolyze with $\mathrm{HCl}(\mathrm{g}) / \mathrm{Et}_{2} \mathrm{O}$ nor with conc. $\mathrm{HCl},{ }^{[11]}$ the amine substituent could be replaced by a methoxy group by reaction with $\mathrm{BF}_{3} \cdot \mathrm{OEt}_{2}$ in methanol to give phosphinate $8(50 \%)$ as a volatile light-yellow liquid (Scheme 2). ${ }^{[12]}{ }^{31} \mathrm{P}$ NMR monitoring of the reaction showed the clean conversion of $7(\delta=-21.5 \mathrm{ppm})$ into product $\mathbf{8}(\delta=-19.6 \mathrm{ppm})$. The presence of the $\mathrm{MeO}$ group is evident from the signals at $\delta\left({ }^{1} \mathrm{H}\right)=3.87 \mathrm{ppm}\left[{ }^{3} J(\mathrm{P}, \mathrm{H})=\right.$ $13.9 \mathrm{~Hz}]$ and $\delta\left({ }^{13} \mathrm{C}\right)=53.3 \mathrm{ppm}\left[{ }^{2} J(\mathrm{P}, \mathrm{C})=5.8 \mathrm{~Hz}\right]$. There are many methods for converting phosphinates into phosphinic chlorides, for example, with $\mathrm{PCl}_{5}, \mathrm{SOCl}_{2}, \mathrm{COCl}_{2},{ }^{[13]}$ enabling further substitution. Instead of dibromide $\mathbf{3}$ we also explored the potential of $i \operatorname{Pr}_{2} \mathrm{NP}(\mathrm{O}) \mathrm{Cl}_{2}$, synthesized from $i \mathrm{Pr}_{2} \mathrm{NPCl}_{2}$ by ozone oxidation, ${ }^{[14]}$ as a precursor to $\mathbf{6}$, but reaction with $\mathrm{BrMgC} \equiv \mathrm{CTMS}$ (4) required temperatures above $50{ }^{\circ} \mathrm{C}$, causing degradation of the Grignard reagent.

\section{Grignard Reactions}

Our first approach was to use both building blocks 3 and 7 to form cyclic P/C frames in a single step. Bis-Grignard reagent 9 could be formed from 7 and $\mathrm{EtMgBr}$ (or $n-\mathrm{BuLi}$ ), as quenching with $\mathrm{TMSCl}$ to give $\mathbf{6}$ suggests, but reaction with 3 at $-78^{\circ} \mathrm{C} \rightarrow$ room temp. did not give the desired ring products. Instead, rapid polymerization occurred above $-20{ }^{\circ} \mathrm{C}$. ${ }^{31} \mathrm{P}$ NMR analysis showed the presence of some unreacted 7 in the reaction mixture. Since the same polymerization reaction occurred in the absence of $\mathbf{3}$, it would appear that bis-Grignard reagent $\mathbf{9}$ is unstable under the reaction conditions and presumably reacts faster intermolecularly with a $\mathrm{P}=\mathrm{O}$ group than with $\mathbf{3}$. Likewise, reaction of a mono-Grignard reagent, generated from 10, with 3 also resulted in a black insoluble material instead of giving triphosphinoyl coupling product 11 (Scheme 3). Compound 10 was obtained from the mono-anion of 7 by $\mathrm{Et}_{3} \mathrm{SiCl}$ quenching, giving a mixture, separable by chromatography, of the product $(53 \%)$, starting material $(17 \%)$, and a disilylated product (trace). ${ }^{[15]}$
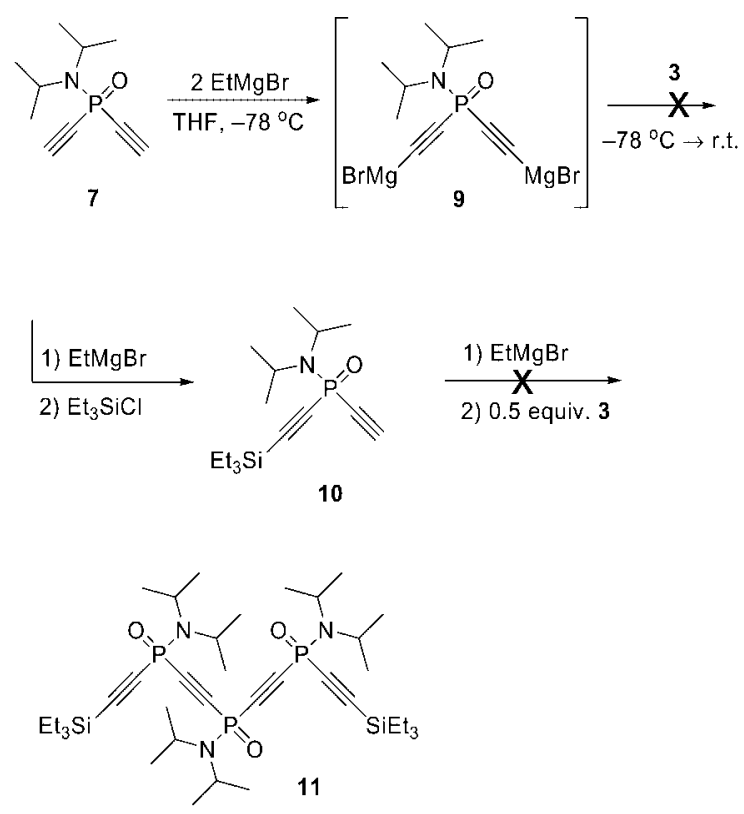

Scheme 3. Attempted Grignard condensation reactions.

The unwanted behavior of the acetylenic phosphane oxides $^{[16]}$ suggests that the acetylide attacks the acetylenic phosphorus atom rather than the $\mathrm{P}-\mathrm{Br}$ bond of $\mathbf{3}$, which relates to the dephosphinylation of $N$-(diphenylphosphanyl)aziridines by organometallic reagents like $\mathrm{PhLi} .{ }^{[12]}$

\section{Acetylene Self-Coupling Reactions}

Our next approach was to use a single building block, ethynylphosphinic amide 10, to form the $\mathrm{P} / \mathrm{C}$ cycles by intermolecular coupling of acetylenic groups. Various coupling procedures may be considered such as the Glaser, ${ }^{[17]}$ Englinton, ${ }^{[18]}$ and Hay ${ }^{[19]}$ reactions which are well known in the formation of acetylene scaffolds of carbon analogues. 
However, only the Pericàs modification of the oxidative Hay coupling reaction, which is also used to synthesize dialkoxybutadiynes from alkoxyacetylenes, ${ }^{[20]}$ gave coupling product 12 in $67 \%$ yield (Scheme 4 ). The protective silyl groups of 12, which slowly degrades in $\mathrm{CDCl}_{3}$, turning brown, were removed at $-78^{\circ} \mathrm{C}$ with TBAF on silica to give $13(60 \%)$, which may exist in two diastereomeric (racemic and meso) forms. Hence, while two ${ }^{31} \mathrm{P}$ NMR chemical shifts would be expected, ${ }^{[6]}$ the observed single one at $\delta=$ $-21.9 \mathrm{ppm}$ may indicate that the difference between them is too small to detect.
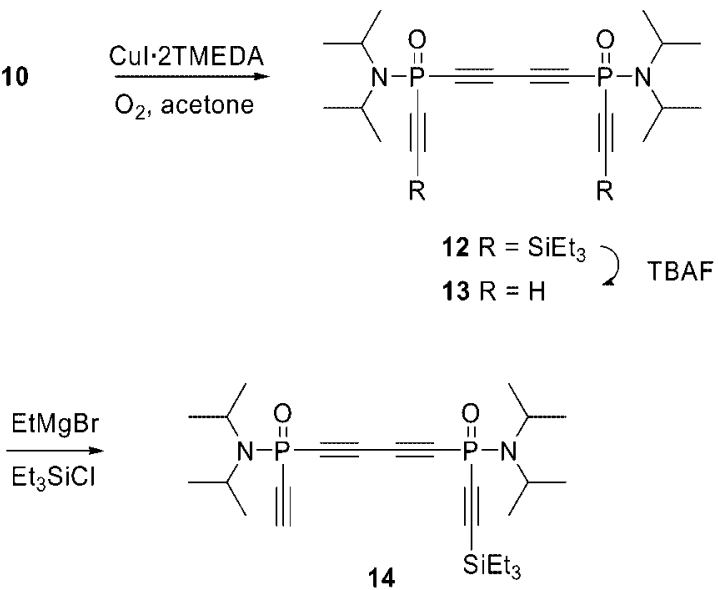

Scheme 4. Oxidative Hay coupling of $\mathbf{1 0 .}$

Cyclic products may be obtained from $\mathbf{1 3}$ either by a double-oxidative Hay coupling reaction ("shot-gun" approach) or in a stepwise manner. The latter requires monosilylation (14), coupling, deprotection, and cyclization steps. However, treatment of $\mathbf{1 3}$ with $\mathrm{EtMgBr}$ or $n$ - BuLi at $-78{ }^{\circ} \mathrm{C}$ $\rightarrow-30{ }^{\circ} \mathrm{C}$ followed by $\mathrm{Et}_{3} \mathrm{SiCl}$ quenching gave 14 in only $13 \%$ yield as a moderately stable pale-white solid $\left[\delta\left({ }^{31} \mathrm{P}\right)\right.$ $=-23.2 \mathrm{ppm}(\mathrm{Si}-\mathrm{C} \equiv \mathrm{C}-\mathrm{P}),-22.2 \mathrm{ppm}(\mathrm{HC} \equiv \mathrm{C}-\mathrm{P})]$, which makes the stepwise route impractical for the synthesis of macrocycles.

The intermolecular coupling of $\mathbf{1 3}$ proved to be more successful. Use of the high-dilution Pericàs modification of the oxidative Hay coupling gave two sets of products that could be isolated by chromatography over silica gel. The ${ }^{1} \mathrm{H}$ NMR spectra of the two sets of products showed the absence of acetylenic proton resonances, thereby suggesting that cyclic products had been formed. Both sets of compounds are stable when obtained as solids, but slowly decompose in solution. The fraction (18\%) that eluted first from the column (silica, ethyl acetate/hexane 2:1, $\mathbf{R}_{f}=0.63-$ 0.73 ) showed four distinct ${ }^{31} \mathrm{P}$ NMR single resonances with different intensities, $\left[\delta\left({ }^{31} \mathrm{P}\right)\left(\mathrm{CDCl}_{3}\right)=-23.7(18 \%),-23.9\right.$ $(30 \%),-24.1(19 \%),-24.2(33 \%)]$. High-resolution mass spectrometry confirmed the mixture consists of isomers of structure 15 (Scheme 5). We were unable to separate the isomers by chromatographic techniques. Given that $\mathbf{1 3}$ may exist as two diastereomers, cross-coupling may lead to four isomers that could display a total of six resonances in the ${ }^{31} \mathrm{P}$ NMR spectrum, that is, isomer $\mathbf{1 5 b}$ with the lowest symmetry has three nonequivalent phosphorus centers, while each of the other three isomers $\mathbf{1 5 a}, \mathbf{c}, \mathbf{d}$ has four equivalent phosphorus centers. ${ }^{[6]}$
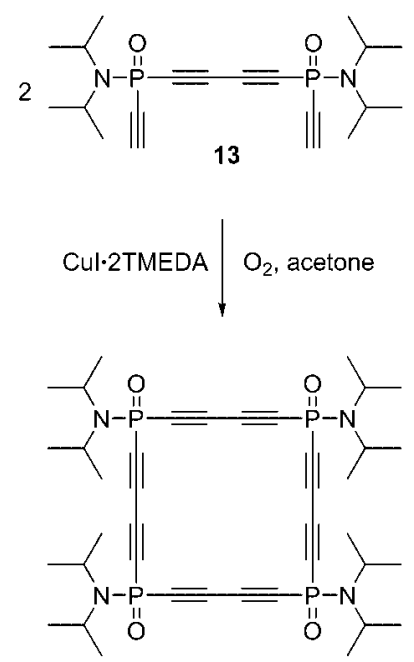

15

Scheme 5. Dimerization of $\mathbf{1 5}$ under oxidative Hay conditions.

The second fraction $\left(12 \%, R_{\mathrm{f}}=0.38-0.48\right)$ showed a sharp singlet at $\delta\left({ }^{31} \mathrm{P}\right)=-24.1 \mathrm{ppm}(16 \%)$ and broad unresolved resonances from $\delta=-23.5$ to $-23.2 \mathrm{ppm}$ (84\%). High-resolution mass spectrometry indicated the mixture likely consists of isomers of trimer $\mathbf{1 6}$ (Scheme 6). We speculatively assign the singlet at $\delta=-24.1 \mathrm{ppm}$ to a single isomer with the phosphorus substituents being either all-cis or all-trans. Crystallization from a dichloromethane/hexane solvent mixture provided a "hair"-like solid that slowly decomposed above $150^{\circ} \mathrm{C}$. Unfortunately, the "hairs", with lengths up to $2 \mathrm{~cm}$, were bent and twisted and not suitable for X-ray crystal structure analysis. These types of hairs are also known as "whiskers" and can be regarded as a solid equivalent of nanotubes. ${ }^{[21]}$ Such an arrangement would be possible through stacking of the macrocycles through hydrogen bonding of the amine substituents to the polar $\mathrm{P}=\mathrm{O}$ groups.

\section{Mixed Acetylene Coupling Reactions}

Our final approach to the construction of $\mathrm{P} / \mathrm{C}$ cycles was to couple 3 with a non-phosphorus-containing linker. The objectives were a more selective process than the self-coupling of $\mathbf{1 3}$ and to circumvent the ill-fated Grignard reaction of 7 with 3 . We opted for 1,2-diethynylbenzene (17) that has, like 7 , an acute angle between the conjugated acetylenic groups and is readily accessible from commercially available $o$ phthalaldehyde. ${ }^{[22]}$ Intermolecular cyclization of building blocks 3 and 17 indeed proved successful (Scheme 7). Thus, addition of the diacetylide 17 , along with $n$-BuLi, to a THF solution of $\mathbf{3}$ gave both the cis and trans isomers of cyclic bis(phosphane oxide) $\mathbf{1 8}(25 \%)$ in a $2: 3$ ratio, as determined by integration of their ${ }^{31} \mathrm{P}$ NMR resonances $\left[\right.$ cis: $\delta\left({ }^{31} \mathrm{P}\right)=$ $-20.4 \mathrm{ppm}$; trans: $\left.\delta\left({ }^{31} \mathrm{P}\right)=-20.2 \mathrm{ppm}\right]$. 


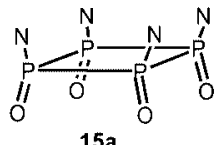

$15 \mathrm{a}$
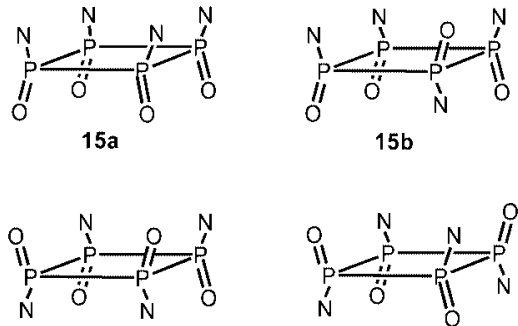

$15 c$

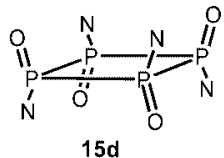

$\begin{aligned} P-P & =P \rightarrow-m \\ N & =N\left(P P_{1}\right)_{2}\end{aligned}$

13

Cul-2TMEDA $\downarrow \mathrm{O}_{2}$, acetone

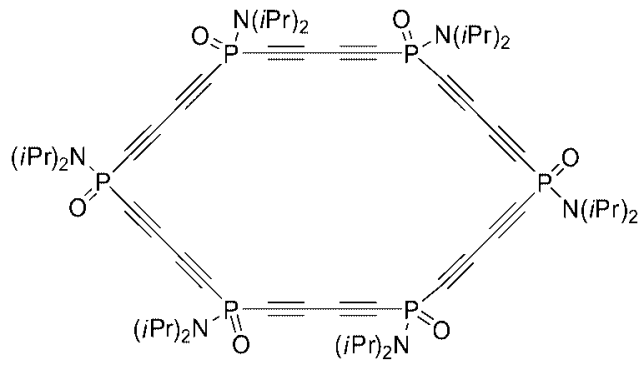

16

Scheme 6. Trimerization of $\mathbf{1 3}$ under oxidative Hay conditions.

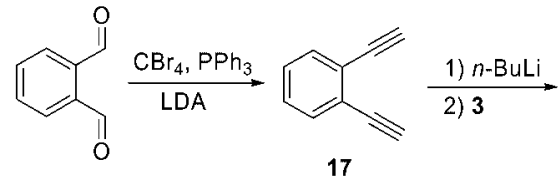<smiles>C#CP(=O)(C#Cc1ccccc1C#CP(=O)(C#Cc1ccccc1C#CP(=O)(C(C)C)N(C(C)C)C(C)C)C(C)C)N(C(C)C)C(C)C</smiles>

Scheme 7. Synthesis of cyclic ethynylphosphane oxide $\mathbf{1 8}$

The single-crystal X-ray structure of the trans isomer (Figure 1) confirmed the formation of the cyclic structure. The pyramidal nature of the phosphorus centers [N1-P1C1 106.37(14) ${ }^{\circ}$, O1-P1-C1 113.098(13) ${ }^{\circ}$ ] causes the ring to be puckered. This is reflected in the dihedral angles of 127.71(17) ${ }^{\circ}$ for $\mathrm{C} 1-\mathrm{P} 1-\mathrm{P} 2-\mathrm{C} 11$ and $116.07(16)^{\circ}$ for $\mathrm{C} 20$ $\mathrm{P} 1-\mathrm{P} 2-\mathrm{C} 10$. The acetylene bonds are only marginally bent [P1-C1-C2 178.4(3) ${ }^{\circ}, \mathrm{C} 1-\mathrm{C} 2-\mathrm{C} 3$ 178.9(3) ${ }^{\circ}$. As expected, the aliphatic ring $\mathrm{C}-\mathrm{C}$ bonds are shortened [C2-C3 $1.435(5) \AA]$ relative to regular $\mathrm{sp}^{3}-\mathrm{sp}^{3} \mathrm{C}-\mathrm{C}$ single bonds. The crystal structure displays normal bond lengths for the $\mathrm{C} \equiv \mathrm{C}$ triple bonds [C1-C2 1.206(4) $\AA$ ] and aromatic phenyl

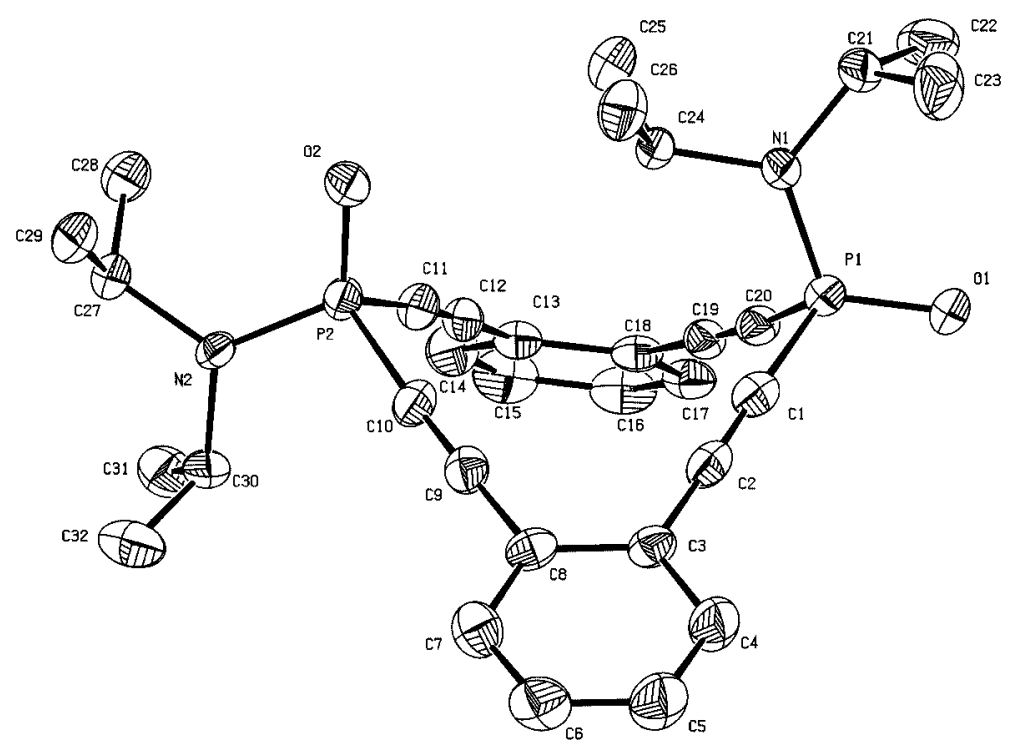

Figure 1. Displacement ellipsoid plot of trans-18 in the crystal form, drawn at the $50 \%$ probability level. Hydrogen atoms and disordered solvent molecules have been omitted for clarity. Selected bond lengths $[\AA ̊ \AA]$, bond angles $\left[^{\circ}\right]$, and torsion angles $\left[^{\circ}\right]$ : P1-O1 1.464(2), P1N1 1.630(3), P1-C1 1.753(4), P1-C20 1.760(3), P2-O2 1.468(2), P2-N2 1.622(2), P2-C10 1.753(3), P2-C11 1.765(3), C1-C2 1.206(4), C2-C3 1.435(5), C3-C8 1.406(4), C8-C9 1.442(4), C9-C10 1.202(4), C11-C12 1.206(4), C12-C13 1.434(5), C13-C18 1.402(4), C18-C19 1.442(4), C19-C20 1.201(4); O1-P1-N1 115.71(13), O1-P1-C1 113.09(13), N1-P1-C1 106.37(14), C1-P1-C20 100.73(15), P1-C1-C2 178.4(3), C1-C2-C3 178.9(3), C2-C3-C8 119.8(3), C3-C8-C9 119.4(3), C8-C9-C10 178.7(3), C9-C10-P2 176.2(3), O1-P1-N1-C21 8.7(3), C1-P1-N1-C21 135.2(2), C20-P1-N1-C21-118.0(2), C2-C3-C8-C9 0.9(5). 
bonds [C3-C4 1.390(4) $\AA$ and C3-C8 1.406(4) $\AA$ ]. The P-C [P1-C1 1.753(4) §], P-N [P1-N1 1.630(3) §], and P-O [P1O1 1.464(2) $\AA$ ] bond lengths are in the expected range. The sulfide and silane analogues have also been reported: They were synthesized by the reaction of 1,2-diethynylbenzene with either bis(phenylsulfonyl) sulfide (for sulfurization) or dichlorophenylsilane (for silylation). ${ }^{[23]}$ The reported crystal structures of these compounds differ considerably from that of bis(phosphane oxide) 18. The silicon analogue was found to be almost planar, while the sulfur analogue was only slightly puckered.

\section{Conclusions}

We have demonstrated that amino-containing acetylenesubstituted phosphane oxides can function as building blocks in the construction of novel $\mathrm{P} / \mathrm{C}$ frames. The building blocks are readily accessible from $\mathbf{3}$ and acetylenic Grignard reagent 4. Under oxidative Hay conditions dimeric unit 13, obtained from monosilylated 10, couples in modest yields to give complex mixtures of the 20- and 30-membered macrocycles $\mathbf{1 5}$ and $\mathbf{1 6}$. Coupling of phosphorus units 3 and 7 by way of a Grignard reaction did not lead to any ring structures, but coupling of $\mathbf{3}$ with lithiated 1,2-diethynylbenzene resulted in a cis/trans mixture of the 14-membered puckered macrocyclic system $\mathbf{1 8}$.

\section{Experimental Section}

$\mathrm{BrMg}-\mathrm{C} \equiv \mathrm{C}-\mathrm{SiMe}_{3}{ }^{[24]}$ and 1,2-diethynylbenzene ${ }^{[22]}$ were prepared according to literature procedures. All experiments, except for the oxidative Hay coupling reactions, were performed under dry nitrogen. Solvents were purified, dried, and degassed by standard techniques. In reactions with wet THF, a few drops of $\mathrm{H}_{2} \mathrm{O}$ were added to THF. NMR spectra were recorded $(T=300 \mathrm{~K})$ with a Bruker Advance 250 or MSL 400 spectrometer $\left({ }^{31} \mathrm{P}: 85 \% \mathrm{H}_{3} \mathrm{PO}_{4} ;{ }^{1} \mathrm{H},{ }^{13} \mathrm{C}\right.$ : internally referenced to residual solvent resonances). High-resolution mass spectra (HRMS) were recorded with a Finnigan Mat 900 spectrometer (EI, $70 \mathrm{eV}$ ). Fast atom bombardment (FAB) mass spectrometry was carried out using a JEOL JMS SX/SX 102A foursector mass spectrometer, coupled to a JEOL MS-MP9021D/UPD system program. Samples were loaded in a matrix solution (3-nitrobenzyl alcohol) onto a stainless steel probe and bombarded with Xenon atoms with an energy of $3 \mathrm{keV}$. During the high-resolution FAB-MS measurements a resolving power of 10000 (10\% valley definition) was used. IR spectra were recorded with a Mattson 6030 Galaxy spectrometer. Elemental analyses were performed by the Microanalytical Laboratory of the Laboratorium für Organische Chemie, ETH, Zürich. Melting points were measured on samples in unsealed capillaries and are uncorrected.

Synthesis of $(\mathbf{P P r})_{2} \mathbf{N P B r}_{2}: \mathrm{PBr}_{3}(6.77 \mathrm{~g}, 25.0 \mathrm{mmol})$ was dissolved in dry diethyl ether $(60 \mathrm{~mL})$ and cooled to $-78^{\circ} \mathrm{C}$. Whilst stirring rapidly, $(i \mathrm{Pr})_{2} \mathrm{NH}(5.06 \mathrm{~g}, 50.0 \mathrm{mmol})$ was added over 30 minutes. The reaction mixture was allowed to warm to room temperature and stirred overnight after which it was filtered and the salts washed with diethyl ether. Evaporation of the solvents afforded a yellow oil. Distillation $\left(4 \times 10^{-2}\right.$ mbar $)$ gave $(i \mathrm{Pr})_{2} \mathrm{NPBr}_{2}$ at $55-$ $60{ }^{\circ} \mathrm{C}$ as a colorless liquid, which solidified upon cooling to give a yield of $6.16 \mathrm{~g}(85 \%)$. The product is very air- and moisture-sensi- tive and slowly decomposes with a color change to yellow/orange, requiring storage below $-20{ }^{\circ} \mathrm{C} .{ }^{31} \mathrm{P}\left\{{ }^{1} \mathrm{H}\right\} \mathrm{NMR}\left(101 \mathrm{MHz}, \mathrm{CDCl}_{3}\right.$, $27^{\circ} \mathrm{C}$ ): $\delta=174.3$ (s) ppm. ${ }^{1} \mathrm{H}$ NMR $\left(250 \mathrm{MHz}, \mathrm{CDCl}_{3}, 27^{\circ} \mathrm{C}\right): \delta$ $=1.26\left(\mathrm{~d},{ }^{3} J_{\mathrm{H}, \mathrm{H}}=6.9 \mathrm{~Hz}, 12 \mathrm{H}, \mathrm{CH}_{3}\right), 3.87-4.05\left(\mathrm{~m},{ }^{3} J_{\mathrm{H}, \mathrm{H}}=\right.$ $6.9 \mathrm{~Hz}, 2 \mathrm{H}, \mathrm{CH}) \mathrm{ppm} .{ }^{13} \mathrm{C}\left\{{ }^{1} \mathrm{H}\right\} \mathrm{NMR}\left(63 \mathrm{MHz}, \mathrm{CDCl}_{3}, 27^{\circ} \mathrm{C}\right): \delta$ $=22.9\left(\mathrm{~d},{ }^{3} J_{\mathrm{P}, \mathrm{C}}=8.6 \mathrm{~Hz}, \mathrm{CH}_{3}\right), 50.8\left(\mathrm{~d},{ }^{2} J_{\mathrm{P}, \mathrm{C}}=13.7 \mathrm{~Hz}, \mathrm{CH}\right) \mathrm{ppm}$. HRMS: calcd. for $\mathrm{C}_{6} \mathrm{H}_{14} \mathrm{Br}_{2} \mathrm{NP} 288.9230$; found 288.9233 for the ${ }^{79} \mathrm{Br}^{79} \mathrm{Br}$ isotope; this isotope is given because it does not interfere with the reference peak.

Oxidation of $(i \mathrm{Pr})_{2} \mathrm{NPBr}_{2}$ with Ozone to $(i \mathrm{Pr})_{2} \mathrm{NP}(\mathrm{O}) \mathrm{Br}_{2}$ (3): $(i \mathrm{Pr})_{2} \mathrm{NPBr}_{2}(2.84 \mathrm{~g}, 9.76 \mathrm{mmol})$ was dissolved in $\mathrm{CH}_{2} \mathrm{Cl}_{2}(100 \mathrm{~mL})$ and cooled to $-78^{\circ} \mathrm{C}$. Dry ozone was bubbled through the reaction mixture for several hours during which time it slowly turned yellow/ orange. The ${ }^{31} \mathrm{P}$ NMR spectrum indicated complete conversion of the starting material to a new product. Evaporation of $\mathrm{CH}_{2} \mathrm{Cl}_{2}$ and extraction with hexane $(2 \times 50 \mathrm{~mL})$ afforded a solution of nearly pure $(i \mathrm{Pr})_{2} \mathrm{NP}(\mathrm{O}) \mathrm{Br}_{2}$ (3). Crystallization from hexane gave 3 $(2.40 \mathrm{~g}, 80 \%)$ as a moisture-sensitive white solid that required storage below $-20^{\circ} \mathrm{C}$. Compound 3 slowly decomposed at temperatures $\geq-20^{\circ} \mathrm{C}$ with a color change to yellow/orange. M.p. 51$52{ }^{\circ} \mathrm{C} .{ }^{31} \mathrm{P}\left\{{ }^{1} \mathrm{H}\right\} \mathrm{NMR}\left(101 \mathrm{MHz}, \mathrm{CDCl}_{3}, 27^{\circ} \mathrm{C}\right): \delta=-34.1$ (s) ppm. ${ }^{1} \mathrm{H} \mathrm{NMR}\left(250 \mathrm{MHz}, \mathrm{CDCl}_{3} .27^{\circ} \mathrm{C}\right): \delta=1.37\left(\mathrm{~d},{ }^{3} J_{\mathrm{H}, \mathrm{H}}=6.8 \mathrm{~Hz}\right.$, $\left.12 \mathrm{H}, \mathrm{CH}_{3}\right), 3.68-3.80\left(\mathrm{~m},{ }^{3} J_{\mathrm{P}, \mathrm{H}}=30.3 \mathrm{~Hz},{ }^{3} J_{\mathrm{H}, \mathrm{H}}=6.8 \mathrm{~Hz}, 2 \mathrm{H}\right.$, $\mathrm{CH}) \mathrm{ppm} .{ }^{13} \mathrm{C}\left\{{ }^{1} \mathrm{H}\right\}$ NMR $\left(63 \mathrm{MHz}, \mathrm{CDCl}_{3}, 27^{\circ} \mathrm{C}\right): \delta=21.7(\mathrm{~d}$, $\left.{ }^{3} J_{\mathrm{P}, \mathrm{C}}=2.4 \mathrm{~Hz}, \mathrm{CH}_{3}\right), 49.8\left(\mathrm{~d},{ }^{2} J_{\mathrm{P}, \mathrm{C}}=5.3 \mathrm{~Hz}, \mathrm{CH}\right) \mathrm{ppm}$. HRMS: calcd. for $\mathrm{C}_{6} \mathrm{H}_{14} \mathrm{Br}_{2} \mathrm{NOP} 306.9159$; found 306.9169 (this is the most abundant ${ }^{79} \mathrm{Br}^{81} \mathrm{Br}$ combination).

Synthesis of $\quad(i \mathrm{Pr})_{2} \mathbf{N P}(\mathrm{O})(\mathbf{C} \equiv \mathbf{C H})_{2} \quad$ (7): $\quad$ TMS $-\mathrm{C} \equiv \mathrm{C}-\mathrm{MgBr}$ ( 2 equiv., $\sim 0.4 \mathrm{M}$ in THF) was added dropwise at $0{ }^{\circ} \mathrm{C}$ to a solution of $(i \mathrm{Pr})_{2} \mathrm{NP}(\mathrm{O}) \mathrm{Br}_{2}(950 \mathrm{mg}, 3.1 \mathrm{mmol})$ in THF $(10 \mathrm{~mL})$ and was slowly warm to room temperature; the ${ }^{31} \mathrm{P}$ NMR spectrum showed complete conversion to the product. The light-brown residual oil, obtained after solvent evaporation, was dissolved in diethyl ether (400 mL), washed with $\mathrm{H}_{2} \mathrm{O}$, and dried with $\mathrm{MgSO}_{4}$. The crude product was dissolved in wet THF $(50 \mathrm{~mL})$, cooled to $0{ }^{\circ} \mathrm{C}$, and TBAF on silica ( $250 \mathrm{mg}, 1-1.5 \mathrm{~mol}-\%$ fluoride per gram) was added. The reaction mixture was stirred for $1 \mathrm{~h}$ and quenched with $\mathrm{H}_{2} \mathrm{O}$. Column chromatography (silica gel, ethyl acetate/hexane, 1:1) yielded $7(415 \mathrm{mg}, 68 \%)$ as a light-yellow solid. M.p: $134-135^{\circ} \mathrm{C}$. ${ }^{31} \mathrm{P}\left\{{ }^{1} \mathrm{H}\right\} \mathrm{NMR}\left(101 \mathrm{MHz}, \mathrm{CDCl}_{3}, 27^{\circ} \mathrm{C}\right): \delta=-21.4(\mathrm{~s}) \mathrm{ppm} .{ }^{1} \mathrm{H}$ NMR $\left(250 \mathrm{MHz}, \mathrm{CDCl}_{3}, 27^{\circ} \mathrm{C}\right): \delta=1.31\left(\mathrm{~d},{ }^{3} J_{\mathrm{H}, \mathrm{H}}=6.8 \mathrm{~Hz}, 12\right.$ $\left.\mathrm{H}, \mathrm{CH}_{3}\right), 3.05\left(\mathrm{~d},{ }^{3} J_{\mathrm{P}, \mathrm{H}}=11.6 \mathrm{~Hz}, 2 \mathrm{H}, \equiv \mathrm{C}-\mathrm{H}\right), 3.60-3.74(\mathrm{~m}$, $\left.{ }^{3} J_{\mathrm{P}, \mathrm{H}}=21.2 \mathrm{~Hz},{ }^{3} J_{\mathrm{H}, \mathrm{H}}=6.8 \mathrm{~Hz}, 2 \mathrm{H}, \mathrm{N}-\mathrm{CH}\right) \mathrm{ppm} .{ }^{13} \mathrm{C}\left\{{ }^{1} \mathrm{H}\right\} \mathrm{NMR}$ $\left(63 \mathrm{MHz}, \mathrm{CDCl}_{3}, 27^{\circ} \mathrm{C}\right): \delta=22.5\left(\mathrm{~d},{ }^{3} J_{\mathrm{P}, \mathrm{C}}=2.1 \mathrm{~Hz}, \mathrm{CH}_{3}\right), 46.9$ $\left(\mathrm{d},{ }^{2} J_{\mathrm{P}, \mathrm{C}}=6.9 \mathrm{~Hz}, \mathrm{~N}-\mathrm{CH}\right), 81.1\left(\mathrm{~d},{ }^{1} J_{\mathrm{P}, \mathrm{C}}=224.7 \mathrm{~Hz}, \mathrm{P}-\mathrm{C} \equiv\right), 88.3$ $\left(\mathrm{d},{ }^{2} J_{\mathrm{P}, \mathrm{C}}=41.5 \mathrm{~Hz}, \equiv \mathrm{CH}\right) \mathrm{ppm}$. HRMS: calcd. for $\mathrm{C}_{10} \mathrm{H}_{16} \mathrm{NOP}$ 197.0970; found 197.0969.

Synthesis of $\mathbf{M e O}-\mathbf{P}(\mathbf{O})(\mathbf{C} \equiv \mathbf{C H})_{2} \quad(\mathbf{8}):(i \mathrm{Pr})_{2} \mathrm{NP}(\mathrm{O})(\mathrm{C} \equiv \mathrm{CH})_{2} \quad(\mathbf{7})$ $(195 \mathrm{mg}, 1.0 \mathrm{mmol}$ ) was dissolved in a 1:1 mixture of $\mathrm{MeOH}$ and $\mathrm{CH}_{2} \mathrm{Cl}_{2}(40 \mathrm{~mL})$ and cooled to $0{ }^{\circ} \mathrm{C} . \mathrm{BF}_{3} \cdot \mathrm{Et}_{2} \mathrm{O}(600 \mu \mathrm{L}, 4.0 \mathrm{mmol})$ was added at once and the reaction mixture was stirred at room temperature for $48 \mathrm{~h}$. The yellow solution was evaporated at reduced pressure and the resulting yellow oil was purified by column chromatography (silica gel, ethyl acetate). $\operatorname{MeOP}(\mathrm{O})(\mathrm{C} \equiv \mathrm{CH})_{2}$ $(50 \mathrm{mg}, 40 \%)$ was isolated as a volatile yellow liquid. ${ }^{31} \mathrm{P}\left\{{ }^{1} \mathrm{H}\right\}$ NMR (101 MHz, $\mathrm{CDCl}_{3}, 27^{\circ} \mathrm{C}$ ): $\delta=-19.7$ (s) ppm. ${ }^{1} \mathrm{H}$ NMR $\left(250 \mathrm{MHz}, \mathrm{CDCl}_{3}, 27^{\circ} \mathrm{C}\right): \delta=3.12\left(\mathrm{~d},{ }^{3} J_{\mathrm{P}, \mathrm{H}}=12.7 \mathrm{~Hz}, 2 \mathrm{H}, \equiv \mathrm{C}-\right.$ $\mathrm{H}), 3.87\left(\mathrm{~d},{ }^{3} J_{\mathrm{P}, \mathrm{H}}=13.9 \mathrm{~Hz}, 3 \mathrm{H}, \mathrm{OCH}_{3}\right) \mathrm{ppm} .{ }^{13} \mathrm{C}\left\{{ }^{1} \mathrm{H}\right\} \mathrm{NMR}$ $\left(63 \mathrm{MHz}, \mathrm{CDCl}_{3}, 27^{\circ} \mathrm{C}\right): \delta=53.3\left(\mathrm{~d},{ }^{2} J_{\mathrm{P}, \mathrm{C}}=5.8 \mathrm{~Hz}, \mathrm{OCH}_{3}\right), 76.2$ $\left(\mathrm{d},{ }^{1} J_{\mathrm{P}, \mathrm{C}}=259.4 \mathrm{~Hz}, \quad \mathrm{P}-\mathrm{C} \equiv\right), 90.6\left(\mathrm{~d},{ }^{2} J_{\mathrm{P}, \mathrm{C}}=48.1 \mathrm{~Hz}, \quad \mathrm{P}-\right.$ $\mathrm{C} \equiv C)$ ppm. 
Synthesis of $\quad(i \mathrm{Pr})_{2} \mathbf{N P}(\mathrm{O})(\mathbf{C} \equiv \mathbf{C H})\left(\mathbf{C} \equiv \mathbf{C S i E t}_{3}\right) \quad(\mathbf{1 0}): \quad(i \mathrm{Pr})_{2} \mathrm{NP}-$ $(\mathrm{O})(\mathrm{C} \equiv \mathrm{CH})_{2} \quad$ (7) $(3.00 \mathrm{~g}, 15.2 \mathrm{mmol})$ was dissolved in $\mathrm{THF}$ $(150 \mathrm{~mL})$ and cooled to $-78{ }^{\circ} \mathrm{C}$. EtMgBr $(1.05$ equivalent, $16 \mathrm{~mL}$, $1 \mathrm{M}$ in THF) was added over a period of $15 \mathrm{~min}$ and the cloudy reaction mixture was stirred for an additional hour before warming it to $-30{ }^{\circ} \mathrm{C}$. $\mathrm{Et}_{3} \mathrm{SiCl}(2.52 \mathrm{~g}, 16.7 \mathrm{mmol})$ was added dropwise and the light-yellow mixture was slowly warmed to room temperature. The solvent was evaporated and the yellow oil with white salts was filtered through a short silica gel column using ethyl acetate/hexane (1:1). Column chromatography (silica gel, ethyl acetate/hexane, 3:1) afforded monosilylated $\mathbf{1 0}(2.50 \mathrm{~g}, 53 \%)$ followed by unreacted starting material 7 (500 mg, 17\%). M.p. $94-95^{\circ} \mathrm{C} .{ }^{31} \mathrm{P}\left\{{ }^{1} \mathrm{H}\right\}$ NMR $\left(101 \mathrm{MHz}, \mathrm{CDCl}_{3}, 27^{\circ} \mathrm{C}\right): \delta=-22.3$ (s) ppm. ${ }^{1} \mathrm{H}$ NMR $\left(\mathrm{CDCl}_{3}\right)$ : $\delta=0.64\left(\mathrm{q},{ }^{3} J_{\mathrm{H}, \mathrm{H}}=7.9 \mathrm{~Hz}, 6 \mathrm{H}, \mathrm{CH}_{2}\right), 0.70\left(\mathrm{t},{ }^{3} J_{\mathrm{H}, \mathrm{H}}=7.9 \mathrm{~Hz}, 9\right.$ $\left.\mathrm{H}, \mathrm{CH}_{2}-\mathrm{CH}_{3}\right), 1.31\left(\mathrm{~d},{ }^{3} \mathrm{~J}_{\mathrm{H}, \mathrm{H}}=6.8 \mathrm{~Hz}, 12 \mathrm{H}, \mathrm{CH}-\mathrm{CH}_{3}\right), 2.98(\mathrm{~d}$, $\left.{ }^{3} J_{\mathrm{P}, \mathrm{H}}=11.3 \mathrm{~Hz}, 1 \mathrm{H}, \equiv \mathrm{CH}\right), 3.62-3.75\left(\mathrm{~m},{ }^{3} J_{\mathrm{P}, \mathrm{H}}=20.8 \mathrm{~Hz},{ }^{3} J_{\mathrm{H}, \mathrm{H}}\right.$ $=6.8 \mathrm{~Hz}, 2 \mathrm{H}, \mathrm{N}-\mathrm{CH}) \mathrm{ppm} .{ }^{13} \mathrm{C}\left\{{ }^{1} \mathrm{H}\right\} \mathrm{NMR}\left(63 \mathrm{MHz}, \mathrm{CDCl}_{3}\right.$, $\left.27^{\circ} \mathrm{C}\right): \delta=3.7\left(\mathrm{~s}, \mathrm{SiCH}_{2}\right), 7.2\left(\mathrm{~s}, \mathrm{CH}_{2} \mathrm{CH}_{3}\right), 22.2\left(\mathrm{~d},{ }^{3} J_{\mathrm{P}, \mathrm{C}}=1.6 \mathrm{~Hz}\right.$, $\left.\mathrm{CH}-\mathrm{CH}_{3}\right), 46.5\left(\mathrm{~d},{ }^{2} J_{\mathrm{P}, \mathrm{C}}=6.9 \mathrm{~Hz}, \mathrm{~N}-\mathrm{CH}\right), 81.6\left(\mathrm{~d},{ }^{1} J_{\mathrm{P}, \mathrm{C}}=\right.$ $220.0 \mathrm{~Hz}, \mathrm{P}-\mathrm{C} \equiv \mathrm{CH}), 87.1\left(\mathrm{~d},{ }^{2} J_{\mathrm{P}, \mathrm{C}}=40.7 \mathrm{~Hz}, \equiv \mathrm{CH}\right), 102.5(\mathrm{~d}$, $\left.{ }^{1} J_{\mathrm{P}, \mathrm{C}}=212.3 \mathrm{~Hz}, \mathrm{P}-C \equiv \mathrm{CSi}\right), 107.3\left(\mathrm{~d},{ }^{2} J_{\mathrm{P}, \mathrm{C}}=30.4 \mathrm{~Hz}, \equiv \mathrm{CSi}\right) \mathrm{ppm}$. HRMS: calcd. for $\mathrm{C}_{16} \mathrm{H}_{30}$ NOPSi 311.1834; found 311.1843.

Oxidative Hay Coupling of $\mathbf{1 0}$ to 12: Compound $\mathbf{1 0}$ (150 mg, $0.48 \mathrm{mmol}$ ) was dissolved in dry acetone $(10 \mathrm{~mL})$ and protected from light. A freshly prepared solution of $5 \mathrm{~mol}-\mathrm{\%} \mathrm{CuI}$ and $10 \mathrm{~mol}-$ $\%$ TMEDA in dry acetone $(10 \mathrm{~mL})$ was added. Air was bubbled through the clear green reaction mixture for $5 \mathrm{~h}$ and dry acetone was added to compensate for solvent evaporation. When the reaction stopped, as indicated by the blue color of the reaction mixture, another portion of $5 \mathrm{~mol}-\% \mathrm{CuI}$ and $10 \mathrm{~mol}-\%$ TMEDA in dry acetone was added. The solvent was evaporated after full conversion was observed (as monitored by ${ }^{31} \mathrm{P}$ NMR spectroscopy) and the green/blue residue was dissolved in diethyl ether $(10 \mathrm{~mL})$, washed with water, and dried with $\mathrm{MgSO}_{4}$. Column chromatography (silica gel, ethyl acetate/hexane, 1:2) afforded 12 (100 mg, $67 \%)$ as a white solid. M.p. $117-118{ }^{\circ} \mathrm{C} .{ }^{31} \mathrm{P}\left\{{ }^{1} \mathrm{H}\right\}$ NMR $(101 \mathrm{MHz}$, $\left.\mathrm{C}_{6} \mathrm{D}_{6}, 27^{\circ} \mathrm{C}\right): \delta=-23.9$ (s) ppm. ${ }^{1} \mathrm{H}$ NMR $\left(250 \mathrm{MHz}, \mathrm{C}_{6} \mathrm{D}_{6}\right.$, $27^{\circ} \mathrm{C}$ ): $\delta=0.45$ (br. q, ${ }^{3} J_{\mathrm{H}, \mathrm{H}}=7.5 \mathrm{~Hz}, 12 \mathrm{H}, \mathrm{Si}-\mathrm{CH}_{2}$ ), 0.91 (br. t, $\left.{ }^{3} J_{\mathrm{H}, \mathrm{H}}=7.5 \mathrm{~Hz}, 18 \mathrm{H}, \mathrm{CH}_{2}-\mathrm{CH}_{3}\right), 1.35\left(\mathrm{~d},{ }^{3} J_{\mathrm{H}, \mathrm{H}}=6.7 \mathrm{~Hz}, 12 \mathrm{H}\right.$, $\left.\mathrm{CH}-\mathrm{CH}_{3}\right), 1.44\left(\mathrm{~d},{ }^{3} \mathrm{~J}_{\mathrm{H}, \mathrm{H}}=6.6 \mathrm{~Hz}, 12 \mathrm{H}, \mathrm{CH}-\mathrm{CH}_{3}\right), 3.60-3.80(\mathrm{~m}$, $\left.{ }^{3} J_{\mathrm{P}, \mathrm{H}}=21.4 \mathrm{~Hz},{ }^{3} J_{\mathrm{H}, \mathrm{H}}=6.7 \mathrm{~Hz}, 4 \mathrm{H}, \mathrm{CH}\right) \mathrm{ppm} .{ }^{13} \mathrm{C}\left\{{ }^{1} \mathrm{H}\right\} \mathrm{NMR}$ $\left(63 \mathrm{MHz}, \mathrm{C}_{6} \mathrm{D}_{6}, 27^{\circ} \mathrm{C}\right): \delta=4.0\left(\mathrm{~s}, \mathrm{Si}-\mathrm{CH}_{2}\right), 7.5\left(\mathrm{~s}, \mathrm{Si}-\mathrm{CH}_{2}-\mathrm{CH}_{3}\right)$, $22.0\left(\mathrm{~s}, \mathrm{CH}-\mathrm{CH}_{3}\right), 22.6\left(\mathrm{~s}, \mathrm{CH}-\mathrm{CH}_{3}\right), 46.9\left(\mathrm{~d},{ }^{2} J_{\mathrm{P}, \mathrm{C}}=7.0 \mathrm{~Hz}, \mathrm{~N}-\right.$ $\mathrm{CH}), 79.6\left(\mathrm{dd},{ }^{2} J_{\mathrm{P}, \mathrm{C}}=40.2 \mathrm{~Hz},{ }^{3} J_{\mathrm{P}, \mathrm{C}}=7.4 \mathrm{~Hz}, \mathrm{P}-\mathrm{C} \equiv C-\mathrm{C} \equiv\right), 82.0$ $\left(\mathrm{dd},{ }^{1} J_{\mathrm{P}, \mathrm{C}}=206.8 \mathrm{~Hz},{ }^{4} J_{\mathrm{P}, \mathrm{C}}=2.2 \mathrm{~Hz}, \mathrm{P}-C \equiv \mathrm{C}-\mathrm{C} \equiv\right), 103.5\left(\mathrm{dd},{ }^{1} J_{\mathrm{P}, \mathrm{C}}\right.$ $\left.=214.4 \mathrm{~Hz},{ }^{6} J_{\mathrm{P}, \mathrm{C}}=3.8 \mathrm{~Hz}, \mathrm{P}-C \equiv \mathrm{C}-\mathrm{Si}\right), 108.0\left(\mathrm{dd},{ }^{2} J_{\mathrm{P}, \mathrm{C}}=30.4 \mathrm{~Hz}\right.$, $\left.{ }^{7} J_{\mathrm{P}, \mathrm{C}}=6.9 \mathrm{~Hz}, \quad \mathrm{P}-\mathrm{C} \equiv C-\mathrm{Si}\right) \mathrm{ppm}$. HRMS: calcd. for $\mathrm{C}_{32} \mathrm{H}_{58} \mathrm{~N}_{2} \mathrm{O}_{2} \mathrm{P}_{2} \mathrm{Si}_{2}$ 620.3512; found 620.3519 .

Desilylation of 12 to $\mathbf{H C} \equiv \mathbf{C}-\mathbf{P}(\mathbf{O})\left[\mathbf{N}(i \mathrm{Pr})_{2}\right]-\mathbf{C} \equiv \mathbf{C}-\mathbf{C} \equiv \mathbf{C}-\mathbf{P}(\mathbf{O})-$ [N $\left.(i \mathbf{P r})_{2}\right]-\mathbf{C} \equiv \mathbf{C H}(\mathbf{1 3})$ : A solution of $\mathbf{1 2}(500 \mathrm{mg}, 0.81 \mathrm{mmol})$ in wet THF $(40 \mathrm{~mL})$ was cooled to $-78^{\circ} \mathrm{C}$. TBAF on silica $(110 \mathrm{mg}, 1.0$ $1.5 \mathrm{mmol}$ fluoride $/ \mathrm{g}$ ) was added and the reaction mixture stirred at $-78^{\circ} \mathrm{C}$ for $2 \mathrm{~h}$, slowly turning black, after which it was quenched with a few drops of water. The black oil that resulted on evaporation of the solvent was purified by column chromatography (silica gel, ethyl acetate/hexane, 1:1) to give $\mathbf{1 3}(190 \mathrm{mg}, 60 \%)$ as a white crystalline solid. M.p. $>140{ }^{\circ} \mathrm{C}$ (decomp.). ${ }^{31} \mathrm{P}\left\{{ }^{1} \mathrm{H}\right\} \quad \mathrm{NMR}$ $\left(101 \mathrm{MHz}, \mathrm{CDCl}_{3}, 27^{\circ} \mathrm{C}\right): \delta=-21.9$ (s) ppm. ${ }^{1} \mathrm{H}$ NMR $(250 \mathrm{MHz}$, $\left.\mathrm{CDCl}_{3}, 27^{\circ} \mathrm{C}\right): \delta=1.31\left(\mathrm{~d},{ }^{3} J_{\mathrm{H}, \mathrm{H}}=6.8 \mathrm{~Hz}, 24 \mathrm{H}, \mathrm{CH}_{3}\right), 3.14(\mathrm{~d}$, $\left.{ }^{3} J_{\mathrm{P}, \mathrm{H}}=11.9 \mathrm{~Hz}, 2 \mathrm{H}, \equiv \mathrm{CH}\right), 3.56-3.75\left(\mathrm{~m},{ }^{3} J_{\mathrm{P}, \mathrm{H}}=21.5 \mathrm{~Hz},{ }^{3} J_{\mathrm{H}, \mathrm{H}}\right.$ $=6.8 \mathrm{~Hz}, 4 \mathrm{H}, \mathrm{N}-\mathrm{CH}) \mathrm{ppm} \cdot{ }^{13} \mathrm{C}\left\{{ }^{1} \mathrm{H}\right\} \mathrm{NMR}\left(100 \mathrm{MHz}, \mathrm{CDCl}_{3}\right.$, $\left.27^{\circ} \mathrm{C}\right): \delta=22.6\left(\mathrm{~m}, \mathrm{CH}_{3}\right), 47.1(\mathrm{~m}, \mathrm{~N}-\mathrm{CH}), 80.1(\mathrm{~m}, \mathrm{P}-\mathrm{C} \equiv \mathrm{CH})$, $80.2(\mathrm{~m}, \mathrm{P}-C \equiv \mathrm{C}-\mathrm{C} \equiv), 80.3\left(\mathrm{dd},{ }^{2} J_{\mathrm{P}, \mathrm{C}}=42.4 \mathrm{~Hz},{ }^{3} J_{\mathrm{P}, \mathrm{C}}=7.8 \mathrm{~Hz}\right.$,
$\mathrm{P}-\mathrm{C} \equiv C-\mathrm{C} \equiv), 89.8\left(\mathrm{~d},{ }^{2} J_{\mathrm{PCC}}=42.8 \mathrm{~Hz}, \mathrm{P}-\mathrm{C} \equiv C \mathrm{H}\right) \mathrm{ppm}$. HRMS: calcd. for $\mathrm{C}_{20} \mathrm{H}_{30} \mathrm{~N}_{2} \mathrm{O}_{2} \mathrm{P}_{2}$ 392.1783; found 392.1765 . $\mathrm{C}_{20} \mathrm{H}_{30} \mathrm{~N}_{2} \mathrm{O}_{2} \mathrm{P}_{2}$ : calcd. C 61.22, H 7.71, N 7.14; found C 61.30, H 7.70, N 7.08.

Monosilylation of 13 to 14: Compound 13 (392 mg, $1.0 \mathrm{mmol}$ ) was dissolved in THF $(10 \mathrm{~mL})$ and cooled to $-78^{\circ} \mathrm{C}$. A solution of EtMgBr $(1 \mathrm{~mL}, 1 \mathrm{M}$ in THF) was added dropwise over $30 \mathrm{~min}$ and the reaction mixture was stirred at $-78^{\circ} \mathrm{C}$ for $1 \mathrm{~h}$ before being allowed to warm to $-30{ }^{\circ} \mathrm{C}$ where it was kept for $30 \mathrm{~min}$ and quenched with $\mathrm{Et}_{3} \mathrm{SiCl}(0.2 \mathrm{~mL}, 1.2 \mathrm{mmol})$. The black residue that resulted on evaporation of the solvent was purified by column chromatography (silica gel, ethyl acetate/hexane, 1:1) to give $\mathbf{1 4}$ as a pale white powder (50 mg, 13\%) that slowly decomposed on exposure to light. Only a ${ }^{31} \mathrm{P}$ NMR spectrum was recorded. A pure ${ }^{1} \mathrm{H}$ NMR spectrum was not obtained because of residual solvents and decomposition products present in the sample. ${ }^{31} \mathrm{P}\left\{{ }^{1} \mathrm{H}\right\} \mathrm{NMR}$ $\left(101 \mathrm{MHz}, \mathrm{CDCl}_{3}, 27^{\circ} \mathrm{C}\right): \delta=-23.2(\mathrm{~s}, \mathrm{Si}-\mathrm{C} \equiv \mathrm{C}-\mathrm{P}),-22.2(\mathrm{~s}, \mathrm{H}-$ $\mathrm{C} \equiv \mathrm{C}-\mathrm{P}) \mathrm{ppm}$.

Cyclization by Oxidative Hay Coupling of 13 to 15 and 16: Compound 13 (500 mg, $1.27 \mathrm{mmol}$ ) was dissolved in dry acetone $(250 \mathrm{~mL})$ and protected from light. A freshly prepared solution of $2 \mathrm{~mol}-\% \mathrm{CuI}(12 \mathrm{mg})$ and $4 \mathrm{~mol}-\%$ TMEDA $(18 \mu \mathrm{L})$ in dry acetone $(25 \mathrm{~mL})$ was added at once. Upon addition of the catalyst, the color of the reaction mixture turned light-yellow. Air was then bubbled through the reaction mixture for $10 \mathrm{~h}$. Every $2 \mathrm{~h}$, another portion of catalyst ( $1 \mathrm{~mol}-\% \mathrm{CuI}$ and $2 \mathrm{~mol} \%$ TMEDA in $10 \mathrm{~mL}$ dry acetone) was added. The reaction was followed by TLC. After full conversion of the starting material, the solvent was evaporated under reduced pressure and the dark-brown residue purified by column chromatography (silica gel, ethyl acetate/hexane, 1:1 and 2:1) to give two sets of products with $R_{f}=0.63-0.73$ for $15(91 \mathrm{mg}$, $18 \%)$ and $R_{f}=0.38-0.48$ for $16(60 \mathrm{mg}, 12 \%)$.

15 (mixture of isomers): M.p. $>175{ }^{\circ} \mathrm{C}$ (decomp.). ${ }^{31} \mathrm{P}\left\{{ }^{1} \mathrm{H}\right\}$ NMR $\left(101 \mathrm{MHz}, \mathrm{CDCl}_{3}, 27^{\circ} \mathrm{C}\right): \delta=-23.1(\mathrm{~s}, 18 \%),-23.3(\mathrm{~s}, 30 \%),-23.5$ (s, 19\%), -23.6 (s, 33\%) ppm. ${ }^{1} \mathrm{H}$ NMR $\left(250 \mathrm{MHz}, \mathrm{CDCl}_{3}, 27{ }^{\circ} \mathrm{C}\right)$ : $\delta=1.33\left(\mathrm{~d},{ }^{3} J_{\mathrm{H}, \mathrm{H}}=6.7 \mathrm{~Hz}, 48 \mathrm{H}, \mathrm{CH}_{3}\right), 3.61-3.78(\mathrm{~m}, 8 \mathrm{H}, \mathrm{N}-$ $\mathrm{CH})$ ppm. ${ }^{13} \mathrm{C}\left\{{ }^{1} \mathrm{H}\right\}$ NMR $\left(63 \mathrm{MHz}, \mathrm{C}_{6} \mathrm{D}_{6}, 27^{\circ} \mathrm{C}\right): \delta=20.2$ (br. s, $\mathrm{CH}_{3}$ ), 45.1 (br., $\left.\mathrm{N}-\mathrm{CH}\right), 78.5-81.9(\mathrm{P}-C \equiv \mathrm{C}$ and $\mathrm{P}-\mathrm{C} \equiv C)$ ppm. HRMS (FAB+): calcd. for $\mathrm{C}_{40} \mathrm{H}_{57} \mathrm{~N}_{4} \mathrm{O}_{4} \mathrm{P}_{4}[\mathrm{M}+\mathrm{H}]$ 781.3330; found 781.3336

16 (single isomer isolated from crystallization in $\mathrm{CH}_{2} \mathrm{Cl}_{2} /$ hexane): M.p. $>150{ }^{\circ} \mathrm{C}$ (decomp.). ${ }^{31} \mathrm{P}\left\{{ }^{1} \mathrm{H}\right\}$ NMR $\left(101 \mathrm{MHz}, \mathrm{CDCl}_{3}, 27^{\circ} \mathrm{C}\right)$ (mixture of isomers): $\delta=-24.1$ (s, 16\%), -23.3 (br., 84\%) ppm. ${ }^{1} \mathrm{H}$ $\operatorname{NMR}\left(\mathrm{CDCl}_{3}\right)$ (single isomer): $\delta=1.35\left(\mathrm{~d},{ }^{3} J_{\mathrm{H}, \mathrm{H}}=6.6 \mathrm{~Hz}, 72 \mathrm{H}\right.$, $\left.\mathrm{CH}_{3}\right), 3.60-3.74\left(\mathrm{~m},{ }^{3} J_{\mathrm{P}, \mathrm{H}}=21.6 \mathrm{~Hz},{ }^{3} J_{\mathrm{H}, \mathrm{H}}=6.6 \mathrm{~Hz}, 12 \mathrm{H}, \mathrm{N}-\right.$ $\mathrm{CH})$ ppm. ${ }^{13} \mathrm{C}\left\{{ }^{1} \mathrm{H}\right\}$ NMR $\left(100 \mathrm{MHz}, \mathrm{CDCl}_{3}, 27^{\circ} \mathrm{C}\right.$ ) (single isomer): $\delta=22.4\left(\mathrm{~s}, \mathrm{CH}_{3}\right), 47.2\left(\mathrm{~d},{ }^{2} J_{\mathrm{P}, \mathrm{C}}=6.77 \mathrm{~Hz}, \mathrm{~N}-\mathrm{CH}\right) ; \mathrm{C} \equiv \mathrm{C}$ resonances too weak to be observed. HRMS (FAB+): calcd. for $\mathrm{C}_{60} \mathrm{H}_{85} \mathrm{~N}_{6} \mathrm{O}_{6} \mathrm{P}_{6}[\mathrm{M}+\mathrm{H}]$ 1171.4956; found 1171.5002.

The HRMS FAB spectrum indicates that a small amount of tetramer $\mathrm{C}_{80} \mathrm{H}_{112} \mathrm{~N}_{8} \mathrm{O}_{8} \mathrm{P}_{8}(\mathrm{~m} / \mathrm{z}=1561.7[\mathrm{M}+1])$ is present in the second set of products after column chromatography.

Cyclization of 1,2-Diethynylbenzene (17) with $(\mathrm{iPr})_{2} \mathrm{NP}(\mathrm{O}) \mathrm{Br}_{2}: 1,2-$ Diethynylbenzene $(380 \mathrm{mg}, 3.0 \mathrm{mmol})$ was dissolved in $\mathrm{THF}$ $(20 \mathrm{~mL})$ and cooled to $-78^{\circ} \mathrm{C} . n$-BuLi $(3.75 \mathrm{~mL}, 1.6 \mathrm{M}$ in hexanes) was added dropwise and the cloudy white solution was stirred for $1.5 \mathrm{~h}$ at $-78^{\circ} \mathrm{C}$ after which time it was added over a period of $30 \mathrm{~min}$ to a solution of $(i \mathrm{Pr})_{2} \mathrm{NP}(\mathrm{O}) \mathrm{Br}_{2}(920 \mathrm{mg}, 3.0 \mathrm{mmol})$ in THF $(100 \mathrm{~mL})$ at $-15^{\circ} \mathrm{C}$ which turned from orange to dark green. After $1 \mathrm{~h}$ at $-15^{\circ} \mathrm{C}$ the reaction mixture was warmed to room temperature and the solvent evaporated. Column chromatography (silica 
gel, ethyl acetate/hexane, 1:1 to pure ethyl acetate) afforded pure trans isomer $18(120 \mathrm{mg}, 15 \%)$ followed by the cis isomer ( $80 \mathrm{mg}$, $10 \%$ ) contaminated with three minor products as UV-sensitive white solids. Crystals of the trans isomer suitable for X-ray diffraction were obtained by crystallization from ethyl acetate/hexane.

18 (trans isomer): M.p $325^{\circ} \mathrm{C}$ (decomp.). ${ }^{31} \mathrm{P}\left\{{ }^{1} \mathrm{H}\right\} \quad \mathrm{NMR}$ $\left(101 \mathrm{MHz}, \mathrm{CDCl}_{3}, 27^{\circ} \mathrm{C}\right): \delta=-20.2$ (s) ppm. ${ }^{1} \mathrm{H}$ NMR $(250 \mathrm{MHz}$, $\left.\mathrm{CDCl}_{3}, 27^{\circ} \mathrm{C}\right): \delta=1.42\left(\mathrm{~d},{ }^{3} J_{\mathrm{H}, \mathrm{H}}=6.8 \mathrm{~Hz}, 24 \mathrm{H}, \mathrm{CH}_{3}\right), 3.83-3.97$ $\left(\mathrm{m},{ }^{3} J_{\mathrm{P}, \mathrm{H}}=21.5 \mathrm{~Hz},{ }^{3} J_{\mathrm{H}, \mathrm{H}}=6.8 \mathrm{~Hz}, 4 \mathrm{H}, \mathrm{N}-\mathrm{CH}\right), 7.38-7.43(\mathrm{~m}, 4$ $\mathrm{H}, \mathrm{Ar}), 7.50-7.55(\mathrm{~m}, 4 \mathrm{H}, \mathrm{Ar}) \mathrm{ppm} .{ }^{13} \mathrm{C}\left\{{ }^{1} \mathrm{H}\right\}$ NMR $(63 \mathrm{MHz}$, $\left.\mathrm{CDCl}_{3}, 27{ }^{\circ} \mathrm{C}\right): \delta=22.9\left(\mathrm{~d},{ }^{3} J_{\mathrm{P}, \mathrm{C}}=1.9 \mathrm{~Hz}, \mathrm{CH}_{3}\right), 47.2\left(\mathrm{~d},{ }^{2} J_{\mathrm{P}, \mathrm{C}}=\right.$ $7.0 \mathrm{~Hz}, \mathrm{~N}-\mathrm{CH}), 90.6\left(\mathrm{~d},{ }^{1} J_{\mathrm{P}, \mathrm{C}}=229.8 \mathrm{~Hz}, \mathrm{P}-\mathrm{C} \equiv\right), 95.9\left(\mathrm{~d},{ }^{2} J_{\mathrm{P}, \mathrm{C}}=\right.$ $42.8 \mathrm{~Hz}, \mathrm{P}-\mathrm{C} \equiv C), 124.4\left(\mathrm{dd},{ }^{3} J_{\mathrm{P}, \mathrm{C}}=4.9 \mathrm{~Hz},{ }^{4} J_{\mathrm{P}, \mathrm{C}}=2.2 \mathrm{~Hz}, i-\mathrm{Ph}\right)$, $130.5(\mathrm{~s}, \mathrm{Ph}), 133.0\left(\mathrm{~d},{ }^{4} J_{\mathrm{P}, \mathrm{C}}=2.0 \mathrm{~Hz}, \mathrm{Ph}\right) \mathrm{ppm}$. HRMS: calcd. for $\mathrm{C}_{32} \mathrm{H}_{36} \mathrm{~N}_{2} \mathrm{O}_{2} \mathrm{P}_{2}$ 542.2252; found 542.2259. $\mathrm{C}_{32} \mathrm{H}_{36} \mathrm{~N}_{2} \mathrm{O}_{2} \mathrm{P}_{2}$ : calcd. $\mathrm{C}$ 70.84, H 6.69, N 5.16; found C 70.75, H 6.54, N 5.15.

18 (cis isomer): ${ }^{31} \mathrm{P}$ NMR (101 MHz, $\mathrm{CDCl}_{3}, 27^{\circ} \mathrm{C}$ ): $\delta=-20.4$ (s) ppm. ${ }^{1} \mathrm{H}$ NMR $\left(250 \mathrm{MHz}, \mathrm{CDCl}_{3}, 27^{\circ} \mathrm{C}\right): \delta=1.42(\mathrm{~m}, 24 \mathrm{H}$, $\mathrm{CH}_{3}$ ), 3.75-3.96 (m, 4 H, N-CH), 7.30-7.46 (m, 4 H, Ar), 7.487.64 (m, 4 H, Ar) ppm.

Crystal Structure Data for 18: $\mathrm{C}_{32} \mathrm{H}_{36} \mathrm{~N}_{2} \mathrm{O}_{2} \mathrm{P}_{2}+$ disordered solvent, $M_{\mathrm{w}}=542.57^{*}$, colorless needle, $0.27 \times 0.09 \times 0.03 \mathrm{~mm}^{3}$, monoclinic, $P 2 / c$ (no. 13), $a=20.6225(3), b=7.5377(1), c=$ 24.2849(5) $\AA, \beta=94.7219(12)^{\circ}, V=3762.18(11) \AA^{3}, Z=4, D_{\mathrm{x}}=$ $0.958 \mathrm{~g} \mathrm{~cm}^{-3 *}, \mu=0.14 \mathrm{~mm}^{-1} *$. (Derived parameters marked with an asterisk $*$ do not contain the contribution of the disordered solvent molecules.) 35739 Reflections were measured on a NoniusKappa CCD diffractometer with rotating anode (graphite monochromator, $\lambda=0.71073 \AA)$ up to a resolution of $(\sin \theta / \lambda)_{\max }=$ $0.56 \AA^{-1}$ at a temperature of $150 \mathrm{~K}$. The reflections were corrected for absorption and scaled on the basis of multiple measured reflections with the SADABS program ${ }^{[25]}(0.83-1.00$ correction range). 5597 Reflections were unique $\left(R_{\text {int }}=0.0837\right)$. The structure was solved by direct methods ${ }^{[26]}$ and refined with SHELXL-97 program $^{[27]}$ against $F^{2}$ for all reflections. The crystal structure contains large voids (1013 $\AA^{3}$ per unit cell) filled with disordered solvent molecules. Their contribution to the structure factors was secured by back-Fourier transformation using the SQUEEZE routine of the PLATON program, ${ }^{[28]}$ accounting for 180 electrons per unit cell. Non-hydrogen atoms were refined with anisotropic displacement parameters. All hydrogen atoms were introduced in geometrically optimized positions and refined with a riding model. $351 \mathrm{~Pa}-$ rameters were refined with no restraints. $R_{1} / w R_{2}[I>2 \sigma(I)]=$ $0.0553 / 0.1458 . R_{1} / w R_{2}$ [all reflections] $=0.0841 / 0.1566, S=1.066$. Residual electron density is between -0.30 and $0.34 \mathrm{e} \AA^{-3}$. Geometry calculations and the check for higher symmetry were performed with the PLATON program. ${ }^{[28]}$

CCDC-625927 contains the supplementary crystallographic data for this paper. These data can be obtained free of charge from The Cambridge Crystallographic Data Centre via www.ccdc.cam.ac.uk/ data_request/cif.

Supporting Information (see footnote on the first page of this article): ${ }^{13} \mathrm{C}$ NMR spectra for the new compounds and HRMS spectra for macrocycles $\mathbf{1 5}$ and $\mathbf{1 6 .}$

\section{Acknowledgments}

This work was supported by the Council for Chemical Sciences of the Netherlands Organization for Scientific Research (NWO/CW). We thank Prof. L. T. Scott of Boston College for insightful information.
[1] a) N. N. P. Moonen, R. Gist, C. Boudon, J.-P. Gisselbrecht, P. Seiler, T. Kawai, A. Kishioka, M. Gross, M. Irie, F. Diederich, Org. Biomol. Chem. 2003, 1, 2032-2034; b) T. Michinobu, J. C. May, J. H. Lim, C. Boudon, J.-P. Gisselbrecht, P. Seiler, M. Gross, I. Biaggio, F. Diederich, Chem. Commun. 2005, 737739; c) N. N. P. Moonen, C. Boudon, J.-P. Gisselbrecht, P. Seiler, M. Gross, F. Diederich, Angew. Chem. Int. Ed. 2002, 41, 3044-3047.

[2] a) R. E. Martin, F. Diederich, Angew. Chem. Int. Ed. 1999, 38, 1350-1377; Angew. Chem. 1999, 111, 1440-1469; b) F. Diederich, L. Gobbi, Top. Curr. Chem. 1999, 201, 43-79; c) M. B. Nielsen, F. Diederich, Synlett 2002, 544-552.

[3] K. B. Dillon, F. Mathey, J. F. Nixon, Phosphorus: The Carbon Copy, Wiley, Chichester, 1998.

[4] a) M. Hissler, P. W. Dyer, R. Réau, Top. Curr. Chem. 2005, 250, 127-163; b) M. Hissler, C. Lescop, R. Réau, J. Organomet. Chem. 2005, 690, 2482-2487; c) C. Hay, M. Hissler, C. Fischmeister, J. Rault-Berthelot, L. Toupet, L. Nyulászi, R. Réau, Chem. Eur. J. 2001, 7, 4222-4236.

[5] a) L. T. Scott, M. Unno, J. Am. Chem. Soc. 1990, 112, 7823 7825 ; b) L. T. Scott, M. J. M. Cooney, Modern Acetylene Chemistry (Eds.: P. J. Stang, F. Diederich), VCH, Weinheim, 1995, ch. 9 , pp. $321-351$.

[6] G. Märk1, T. Zollitsch, P. Kreitmeier, M. Prinzhorn, S. Reithinger, E. Eibler, Chem. Eur. J. 2000, 6, 3806-3820.

[7] a) R. J. P. Corriu, C. Guérin, B. J. L. Henner, A. Jolivet, J. Organomet. Chem. 1997, 530, 39-48; b) Y.-C. Chang, J.-C. Lee, F.-E. Hong, Organometallics 2005, 24, 5686-5695; c) S. B. Bushuk, F. H. Carre, D. M. H. Guy, W. E. Douglas, Y. A. Kalvinkovskya, L. G. Klapshina, A. N. Rubinov, A. P. Stupak, B. A. Bushuk, Polyhedron 2004, 23, 2615-2623.

[8] a) S. Rumthao, O. Lee, Q. Sheng, W. Fu, D. C. Mulhearn, D. Crich, A. D. Mesecar, M. E. Johnson, Bioorg. Med. Chem. Lett. 2004, 14, 5165-5170; b) V. Vicente, A. Fruchier, M. Taillefer, C. Combes-Chamalet, I. J. Scowen, F. Plenat, H.-J. Cristau, New J. Chem. 2004, 28, 418-424.

[9] R. B. King, N. D. Sadanani, J. Org. Chem. 1985, 50, 17191722 .

[10] K. Toyota, M. Shibata, M. Yoshifuji, Bull. Chem. Soc. Jpn. 1995, 68, 2633-2638.

[11] a) T. Koizumi, P. Haake, J. Am. Chem. Soc. 1973, 95, 80738079 ; b) E. I. Matrosov, E. E. Kryuchkov, E. E. Nifantyev, A. G. Kozachenko, M. I. Kabachnik, Phosphorus Sulfur 1982, 13, 69-78; c) M. J. P. Harger, P. A. Shimmin, Tetrahedron 1992, 48, 7539-7550; d) R. P. Polniaszek, J. Org. Chem. 1992, 57, 5189-5195.

[12] A. A. Cantrill, H. M. I. Osborn, J. Sweeney, Tetrahedron 1998, 54, 2181-2208.

[13] a) O. Korpiun, R. A. Lewis, J. Chickos, K. Mislow, J. Am. Chem. Soc. 1968, 90, 4842-4846; b) F. Fredoueil, M. Evain, D. Massiot, M. Bujoli-Doeuff, B. Bujoli, J. Mater. Chem. 2001, 11, 1106-1110; c) M. Finke, H.-J. Kleiner, Justus Liebigs Ann. Chem. 1974, 741-750.

[14] A.-M. Caminade, F. El Khatib, A. Baceiredo, M. Koenig, Phosphorus Sulfur 1987, 29, 365-367.

[15] The mono-TMS adduct was prepared by following the same procedure but by using TMSCl. However, desilylation was observed upon purification by column chromatography on silica gel.

[16] a) R. M. Acheson, P. J. Ansell, J. R. Murray, J. Chem. Res. (M) 1986, 3001; R. M. Acheson, P. J. Ansell, J. R. Murray, J. Chem. Res. (S) 1986, 378; b) S. G. Dutremez, C. Guerin, B. J. L. Henner, V. Tomberli, Phosphorus Sulfur Silicon Relat. Elem. 2000, 160, 251-269.

[17] a) C. Glaser, Ber. Dtsch. Chem. Ges. 1869, 2, 422-424; b) C. Glaser, Justus Liebigs Ann. Chem. 1870, 154, 137-171.

[18] a) G. Eglinton, A. R. Galbraith, Chem. Ind. (London) 1956, 737-738; b) O. M. Behr, G. Eglinton, A. R. Galbraith, R. A. Raphael, J. Chem. Soc. 1960, 3614-3625. 
[19] a) A. S. Hay, J. Org. Chem. 1960, 25, 1275-1276; b) A. S. Hay, J. Org. Chem. 1962, 27, 3320-3321.

[20] E. Valenti, M. A. Pericàs, F. Serratosa, J. Am. Chem. Soc. 1990, $112,7405-7406$.

[21] For a description of whiskers, see also: P. van der Sluis, Ph. D. Thesis, Utrecht University, 1989, ch. 4, pp. 31-48.

[22] M. L. G. Borst, R. E. Bulo, C. W. Winkel, D. J. Gibney, A. W. Ehlers, M. Schakel, M. Lutz, A. L. Spek, K. Lammertsma, J. Am. Chem. Soc. 2005, 127, 5800-5801.

[23] H. Zhang, K. T. Lam, Y. L. Chen, T. Mo, C. C. Kwok, W. Y. Wong, M. S. Wong, A. W. M. Lee, Tetrahedron Lett. 2002, 43, 2079-2082.
[24] L. Brandsma, Preparative Acetylenic Chemistry, 2nd ed., Elsevier, New York, 1988.

[25] G. M. Sheldrick, SADABS: Area-Detector Absorption Correction, v2.10, Universität Göttingen, Germany, 1999.

[26] A. Altomare, M. C. Burla, M. Camalli, G. L. Cascarano, C. Giacovazzo, A. Guagliardi, A. G. G. Moliterni, G. Polidori, R. Spagna, J. Appl. Crystallogr. 1999, 32, 115-119.

[27] G. M. Sheldrick, SHELXL-97: Program for crystal structure refinement, University of Göttingen, Germany, 1997.

[28] A. L. Spek, J. Appl. Crystallogr. 2003, 36, 7-13.

Received: October 6, 2006

Published Online: January 8, 2007 